\title{
Safety of Hydrogen Systems Installed in Outdoor Enclosures
}

Hydrogen Safety Panel

NF Barilo, Program Manager

November 2013

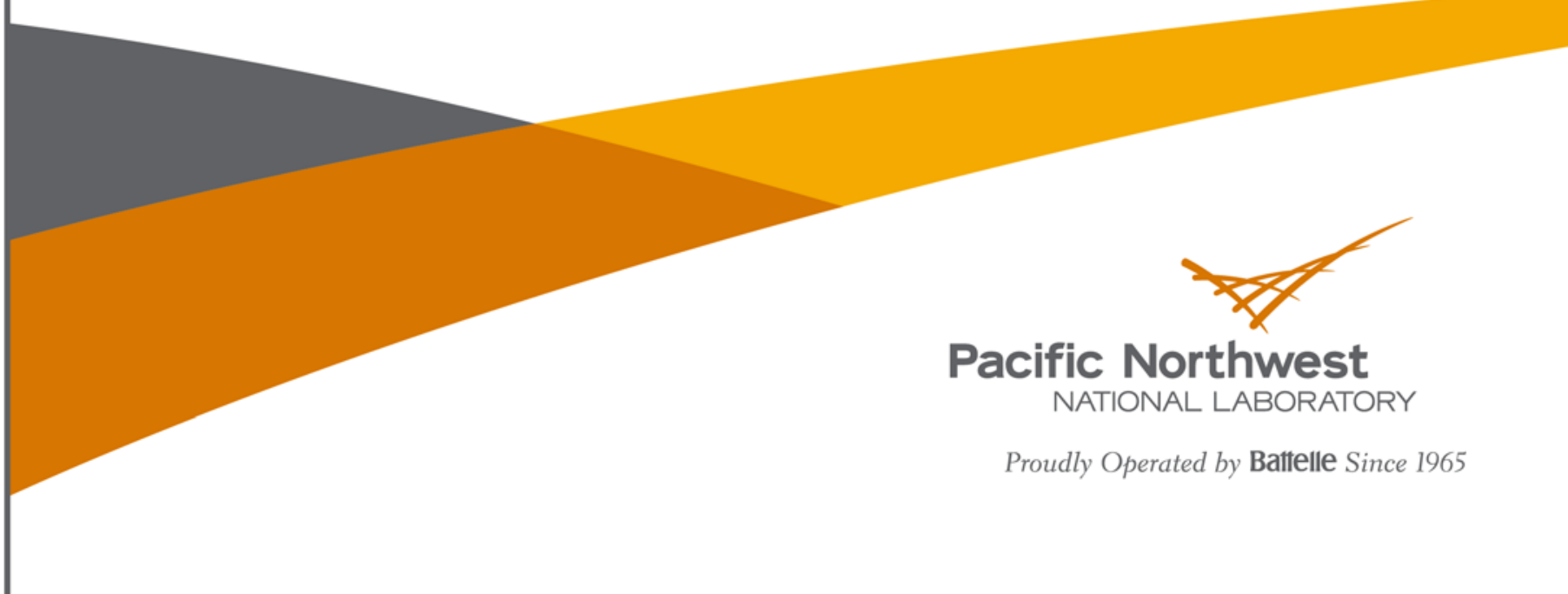




\title{
DISCLAIMER
}

This report was prepared as an account of work sponsored by an agency of the United States Government. Neither the United States Government nor any agency thereof, nor Battelle Memorial Institute, nor any of their employees, makes any warranty, express or implied, or assumes any legal liability or responsibility for the accuracy, completeness, or usefulness of any information, apparatus, product, or process disclosed, or represents that its use would not infringe privately owned rights. Reference herein to any specific commercial product, process, or service by trade name, trademark, manufacturer, or otherwise does not necessarily constitute or imply its endorsement, recommendation, or favoring by the United States Government or any agency thereof, or Battelle Memorial Institute. The views and opinions of authors expressed herein do not necessarily state or reflect those of the United States Government or any agency thereof.

\author{
PACIFIC NORTHWEST NATIONAL LABORATORY \\ operated by \\ BATTELLE \\ for the \\ UNITED STATES DEPARTMENT OF ENERGY \\ under Contract DE-AC05-76RL01830 \\ Printed in the United States of America \\ Available to DOE and DOE contractors from the \\ Office of Scientific and Technical Information, \\ P.O. Box 62, Oak Ridge, TN 37831-0062; \\ ph: (865) 576-8401 \\ fax: $(865) 576-5728$ \\ email: reports@adonis.osti.gov \\ Available to the public from the National Technical Information Service \\ 5301 Shawnee Rd., Alexandria, VA 22312 \\ ph: (800) 553-NTIS (6847) \\ email: orders@ntis.gov <http://www.ntis.gov/about/form.aspx> \\ Online ordering: http://www.ntis.gov
}




\section{Safety of Hydrogen Systems Installed in Outdoor Enclosures}

Hydrogen Safety Panel

NF Barilo, Program Manager

November 2013

Prepared for

the U.S. Department of Energy

under Contract DE-AC05-76RL01830

Pacific Northwest National Laboratory

Richland, Washington 99352 


\section{Contents}

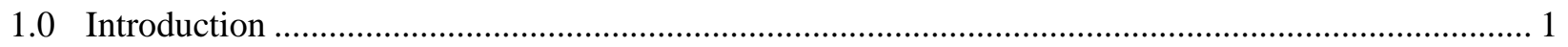

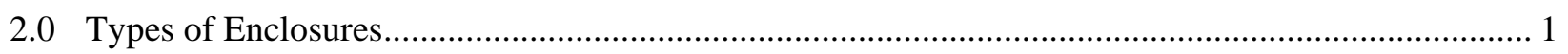

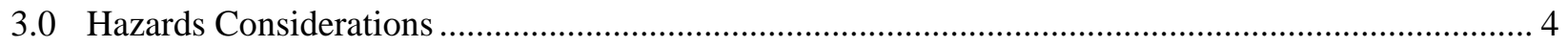

4.0 Preventing or Mitigating the Potential Hazards............................................................................. 5

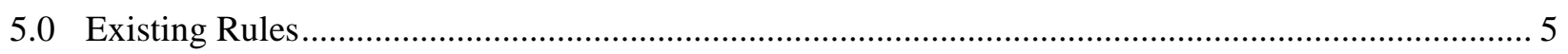

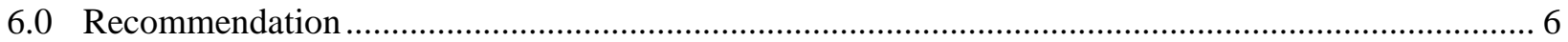

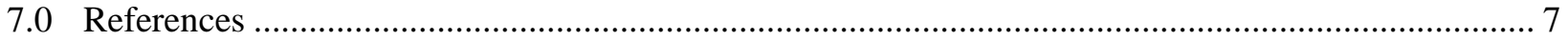




\subsection{Introduction}

The Hydrogen Safety Panel brings a broad cross-section of expertise from the industrial, government, and academic sectors to help advise the U.S. Department of Energy's (DOE) Fuel Cell Technologies Office through its work in hydrogen safety, codes, and standards. The Panel's initiatives in reviewing safety plans, conducting safety evaluations, identifying safety-related technical data gaps, and supporting safety knowledge tools and databases cover the gamut from research and development to demonstration and deployment. The Panel's recent work has focused on the safe deployment of hydrogen and fuel cell systems in support of DOE efforts to accelerate fuel cell commercialization in early market applications: vehicle refueling, material handling equipment, backup power for warehouses and telecommunication sites, and portable power devices.

This paper resulted from observations and considerations stemming from the Panel's work on early market applications. This paper focuses on hydrogen system components that are installed in outdoor enclosures. These enclosures might alternatively be called "cabinets," but for simplicity, they are all referred to as "enclosures" in this paper. These enclosures can provide a space where a flammable mixture of hydrogen and air might accumulate, creating the potential for a fire or explosion should an ignition occur. If the enclosure is large enough for a person to enter, and ventilation is inadequate, the hydrogen concentration could be high enough to asphyxiate a person who entered the space.

Manufacturers, users, and government authorities rely on requirements described in codes to guide safe design and installation of such systems. Except for small enclosures used for hydrogen gas cylinders (gas cabinets), fuel cell power systems, and the enclosures that most people would describe as buildings, there are no hydrogen safety requirements for these enclosures, leaving gaps that must be addressed. This paper proposes that a technical basis be developed to enable code bodies to write requirements for the range of enclosures from the smallest to the largest.

\subsection{Types of Enclosures}

Enclosures are used for a variety of reasons, including weather protection, physical security of the systems, prevention of tampering, hazard mitigation, and aesthetics. In the course of its work, the Panel has observed various types of enclosures used for hydrogen systems, including the following. 


\section{Gas Cabinet}

- Generally limited to three cylinders and tubing and valves.

- Negative pressure ventilation is required. Empty cylinders are typically replaced with full cylinders.

- A person normally cannot enter the cabinet.

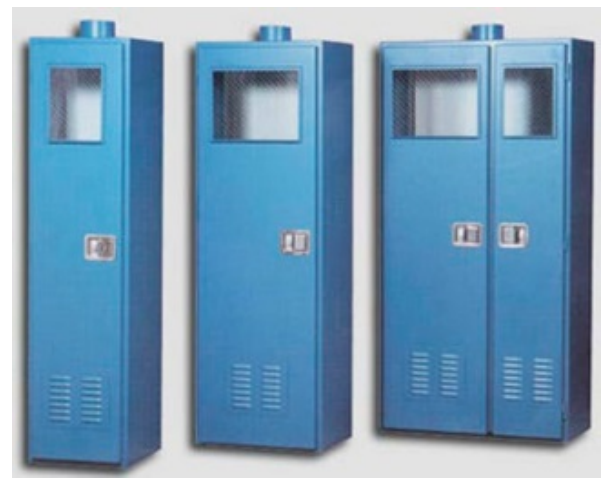

\section{Cylinder Enclosures}

- Contains cylinders, tubing and valves, and solenoid actuator.

- Used as a source of hydrogen for many applications. The cylinders may be replaced or refilled in place by a supplier from a bulk transport. Passive ventilation is typically provided.

- A person normally cannot enter the enclosure.

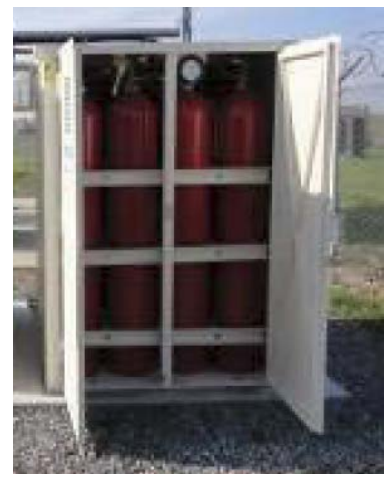

\section{Dispenser}

- Typically contains tubing and valves, solenoid actuators, instrumentation, and similar components.

- Hydrogen is typically supplied to the enclosure by a piping system that is connected to the bulk source. Varying degrees of natural ventilation are typically provided.

- A person normally cannot enter the enclosure.

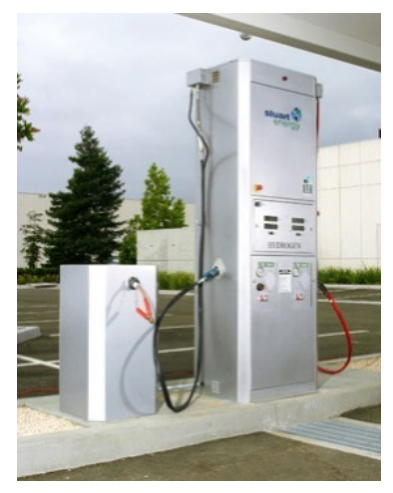

\section{Backup Power Enclosures}

- Contains cylinders, tubing and valves, fuel cells, solenoid actuator, and instrumentation.

- The cylinders are usually in a separate compartment from the other equipment. The cylinders may be replaced or refilled by a supplier from a bulk transport. Passive ventilation is typically provided.

- A person normally cannot enter the enclosure.

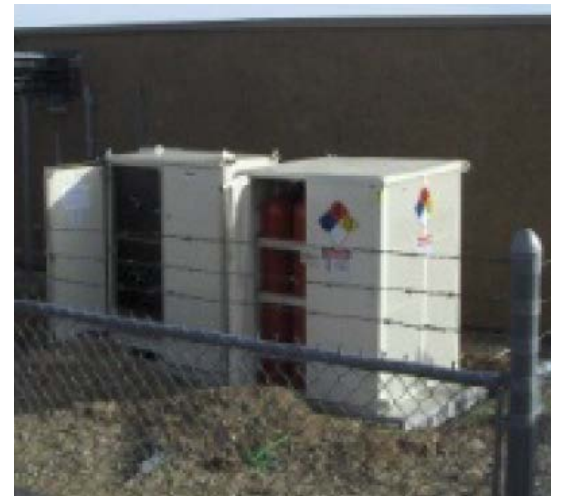




\section{ISO Container 1 - Storage}

- Contains stationary tanks, tubing and valves, and solenoid actuator.

- Gas is typically supplied to the tanks from transport vehicles or from process operations where hydrogen is generated on site. Passive ventilation is typically provided.

- A person normally cannot enter the enclosure.

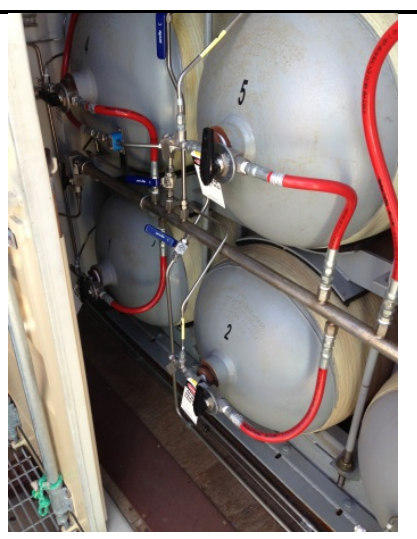

\section{ISO Container 2 - Generation, Compression, Storage, Dispensing}

- May contain tubing and valves, pressure vessels, compressors, fuel cells, solenoid actuator, instrumentation, and electric heating elements.

- May be used for hydrogen generation, purification, compression, storage, dispensing, or a combination. Passive ventilation is typically provided.

- A person would not enter the enclosure for normal operation or service of the equipment when the

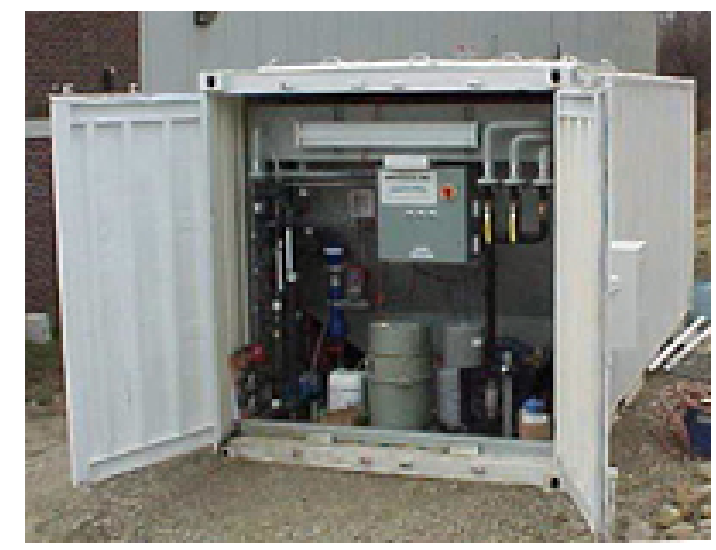
space provided constrains entry.

\section{ISO Container 3 - Generation, Compression, Storage, Dispensing}

- May contain tubing and valves, pressure vessels, compressors, fuel cells, solenoid actuator, instrumentation, and electric heating elements.

- May be used for hydrogen generation, purification, compression, storage, dispensing, or a combination. Mechanical ventilation is typically provided.

- A person can enter the enclosure.

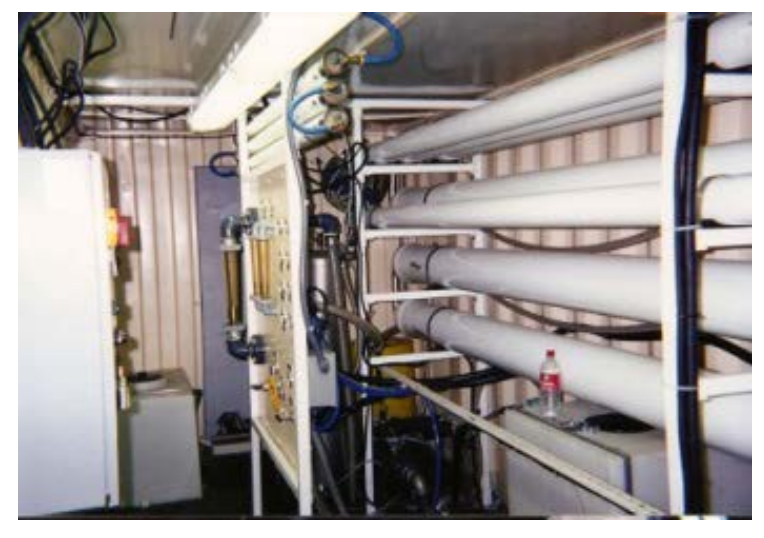


Except for the gas cabinets, fuel cell power systems, and structures like ISO Container 3 that might be considered buildings, there is currently no consistent set of requirements that can be applied by designers or regulators that govern the construction of the enclosures, ventilation systems, leak or fire detection systems, electrical classification, and separation distances between the enclosure and other structures. While the ISO Container 3 might be considered a building by many code officials, interpretations by regulators can vary widely, leading to inconsistent application of rules.

Without clear requirements for the different types of enclosures, designers have little guidance on how to design safe systems and code officials have a difficult time determining which code requirements may apply to which enclosures.

\subsection{Hazards Considerations}

The potential consequences of hydrogen leaks inside the enclosure include the following.

1. Jet Fire: The hydrogen leaks in the form of a jet, typically at a failed static or dynamic seal. The jet is ignited, resulting in a jet fire that will likely impinge on adjacent surfaces and cause damage.

2. Explosion: The hydrogen leaks inside the enclosure. If the concentration is in the flammable range and finds an ignition source, the explosion may damage the enclosure and its contents, and adjacent structures. A nearby person might be injured.

3. Ceiling Layer Fire: A slow leak accumulates under the ceiling layer at a concentration and depth that, upon encountering an ignition source, can burn without producing sufficient overpressure to damage the enclosure. Oxygen vitiation prevents all the hydrogen from burning until someone opens the enclosure door and creates a backdraft condition that can injure a person in the area around the open door.

4. Asphyxiation: The hydrogen leaks inside the enclosure. The concentration of hydrogen reduces oxygen concentration to the point where a person working inside the enclosure loses consciousness. The person could be injured or die.

5. Nothing Hazardous: This is what happens most of the time. The hydrogen leaks inside the enclosure. If the concentration is not high enough or is too high, it won't burn. If the concentration is in the flammable range, but does not encounter an ignition source, it won't burn. If the concentration is high enough and no one is present, no one will be asphyxiated.

If any of the first four consequences occur, an incident may result in an emergency response, an accident investigation, extended downtime, and adverse publicity. While enclosures can create specific safety hazards, enclosures can also be used to reduce hazards such as weather damage and tampering. A properly designed and installed enclosure can balance these hazards and offer an overall safer system. 


\subsection{Preventing or Mitigating the Potential Hazards}

Various approaches can be taken to prevent or mitigate the potential hazards. These include the following:

- Lower the probability of a leak to an acceptable level

- Provide enough ventilation so that credible leaks will not result in a concentration in the enclosure sufficient to explode, asphyxiate, or allow a backdraft condition

- Install interlocks that will isolate the sources of hydrogen when a hydrogen leak is detected

- Eliminate known ignition sources from inside the enclosure

- Provide explosion controls such that the hazard is minimized

- Locate enclosures away from other structures and where people are likely to be

Unfortunately, not enough is known about credible hydrogen leak rates to prescribe specific approaches to prevent or mitigate the hazards. Although some work has been done to define leak probabilities and credible leak sizes (LaChance et al. 2009), more work is needed.

\subsection{Existing Rules}

Some of these enclosures, particularly gas cabinets, have been safely used within industrial hydrogen applications for several decades with few reported incidents. This success can be contributed, at least in part, to the existing rules governing the design and installation of selected enclosures. Rules for enclosures are described in the following codes and standards:

\begin{tabular}{ll}
\hline \multicolumn{1}{c}{ Relevant Coverage } & \multicolumn{1}{c}{ Codes and Standards } \\
\hline Gas cabinet design and installation & NFPA 2 \\
Packaged, self-contained fuel cell power system design & NFPA 55 \\
Packaged, self-contained fuel cell power system installation & IEC 62282-3-100 \\
& NFPA 2 \\
Buildings & NFPA 853 \\
& NFPA 1 \\
& NFPA 2 \\
& NFPA 5000 \\
& International Building Code \\
\hline
\end{tabular}

While certain types of enclosures are covered by applicable rules, there are still gaps in the coverage. This paper proposes the development of a technical basis for rules to cover the technical gaps that exist for enclosures, and, if appropriate, modifications to the existing rules. 


\subsection{Recommendation}

It is recommended that a technical basis for creating prescriptive and performance-based requirements be developed for the range of enclosures used for hydrogen systems from the smallest to the largest. Variables that need to be considered include the following:

- Leak rate, which is a function of hydrogen pressure and the components inside the enclosure

- Probability of a leak, accounting for scenarios such as normal equipment degradation, potential for incompatible materials, and improper installations

- Ventilation required to prevent flammable hydrogen ceiling layer concentrations from developing

- Explosion protection measures other than leak prevention and ventilation

- Damage or injuries that might result from a leak

- Necessary separation distances between enclosures and other exposures

The technical basis would describe measures that can be taken to reduce the risk of unacceptable hazards for various enclosures. Ideally, the technical basis would allow for an empirical assessment of any enclosure based on a set of parameters. A designer would then apply the correct or at least preferred methods of control, and enable code officials to approve an installation.

For the more complex systems, the most practical approach to implementation may be to transform the technical basis into product standards and provide for third-party certification to allow code officials to confirm that the enclosure conforms to the product standard. Since the development of product standards has historically taken years to accomplish, and since these enclosures are being installed at many locations today, there is a need for interim guidance for designers and code officials. The technical basis should provide that guidance.

The technical basis should have the following attributes:

1. Summary of applicable existing technical publications and published codes and standards.

2. Consideration of enclosures from the smallest (gas cabinets) to the largest (buildings). Even though there are existing rules for some of the enclosures, the existing rules may need to be modified to make sense when the continuum of enclosures is examined. Suggested changes to existing codes and standards should be included.

3. Technically sound guidance that can be used by designers and code officials for the range of enclosures. The guidance should address at least the following:

- Ways to lower the probability of a leak to an acceptable level

- Ventilation requirements

- Interlocks needed to isolate the sources of hydrogen when the detected hydrogen concentration exceeds predetermined values

- Elimination of ignition sources from inside the enclosure 
- Explosion controls

- Separation distances

It is likely that not all of the provisions described above will be needed for all enclosures. For example, an enclosure may be safe enough if it has adequate ventilation, sufficient interlocks, or adequate separation.

4. Logical categories of enclosures to which specific guidance is to be applied. Categories might be defined by internal volume, the amount of hydrogen stored, leak potential, or a combination of these parameters.

5. Guidance that can be applied to the ongoing development of the prescriptive standards and codes, and to the ongoing development of performance codes

\subsection{References}

IEC 62282-3-100. Fuel cell technologies, Part 3-100: Stationary fuel cell power systems - Safety. International Electrotechnical Commission, Geneva, Switzerland.

LaChance J, W Houf, B Middleton, and L Fluer. 2009. Analyses to Support Development of RiskInformed Separation Distances for Hydrogen Codes and Standards. SAND2009-0874, Sandia National Laboratories, Albuquerque, New Mexico.

NFPA 1. Fire Code. National Fire Protection Association, Quincy, Massachusetts.

NFPA 2. Hydrogen Technologies Code. National Fire Protection Association, Quincy, Massachusetts.

NFPA 5000. Building Construction and Safety Code. National Fire Protection Association, Quincy, Massachusetts.

NFPA 55. Compressed Gases and Cryogenic Fluids Code. National Fire Protection Association, Quincy, Massachusetts.

NFPA 853. Standard for the Installation of Stationary Fuel Cell Power Systems. National Fire Protection Association, Quincy, Massachusetts. 


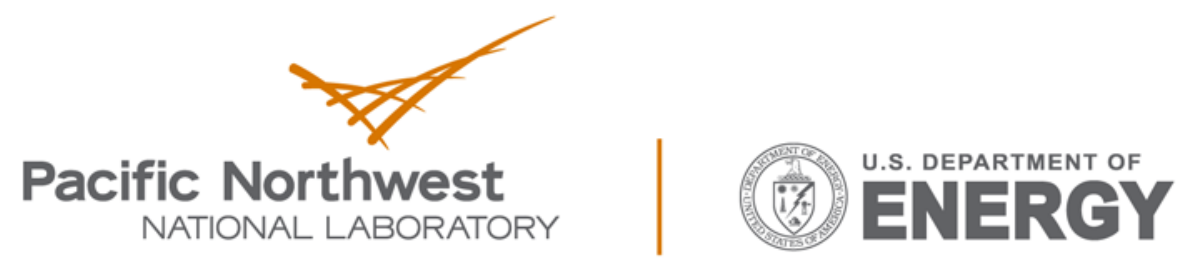

Proudly Operated by Battelle Since 1965

902 Battelle Boulevard

P.O. Box 999

Richland, WA 99352

1-888-375-PNNL (7665)

www.pnnl.gov 